\title{
Atmospheric Turbidity and Aerosol Size Distribution in Winter at Tsukuba: Effects of the Eruption of El Chichon
}

\author{
By Shoji Asano, Masayuki Sekine ${ }^{1}$, Masaharu Kobayashi², and Keizo Murai ${ }^{3}$ \\ Meteorological Research Institute, Yatabe, Tsukuba, Ibaraki 305 Japan \\ (Manuscript received 16 January 1985, in revised form 28 March 1985)
}

\begin{abstract}
The aerosol optical thickness of the atmosphere was measured using a spectropyrheliometer at Tsukuba for three winter seasons from October 1980 to March 1983. The optical thickness was abnormally large in the ('82-'83) winter, because of the enhancement of the stratospheric aerosols due to the volcanic eruptions of El Chichon. Size distributions of aerosols in the vertical air column were inferred, which show characteristic features of bimodal distribution for the pre-El Chichon season and power law distribution for the postEl Chichon season. Optical properties of the El Chichon volcanic aerosols have been estimated; the stratospheric optical thickness was about 0.1 on the wavelength average in the ('82-'83) winter, and aerosol size distributions were relatively monodispersive with a mode radius around $0.3 \mu \mathrm{m}$. Possible effects of the enhanced stratospheric aerosols on the solar radiation budget were estimated and compared with available observations. The El Chichon induced aerosols in the ('82-'83) winter could reduce the total solar radiation on the ground by as much as $3-4 \%$ on cloudless days, and enhance the spherical albedo by about $10 \%$.
\end{abstract}

\section{Introduction}

The atmospheric optical thickness due to extinction by aerosols is an important parameter, not only as a measure of the atmospheric turbidity but also as a factor affecting the radiation budget in the atmosphere. By measuring attenuation of the direct solar beam at selected wavelengths, it is possible to estimate spectral distributions of the aerosol optical thickness as well as aerosol size distributions (King et al., 1978; Yamamoto and Tanaka, 1969). Spectral measurements of the directly transmitted solar radiation have been conducted using a spectro-pyrheliometer at the MRI (Meteorological Research Institute) at Tsukuba $\left(36.1^{\circ} \mathrm{N}, 140.1^{\circ} \mathrm{E}\right)$ on cloud-free days in three winter seasons between October 1980

1. Applied Meteorological Division, JMA, Ootemachi, Tokyo 100.

2. Asahigaoka 5-2-13, Hino 191.

3. Meteorological College, Kashiwa 277. and March 1983. During the period, the Mexican volcano, El Chichon, happened to erupt in late March and early April of 1982, introducing a massive amount of gases and particles into the stratosphere. The resulting enhancement of the stratospheric optical thickness has globally disturbed the solar radiation reaching the ground (Baker et al., 1984; $\mathrm{Hu}, 1984$; Obata, 1984; Wendler, 1984 ; Yamauchi and Shimura, 1984).

In this paper we present time variations of the aerosol optical thickness, and characteristic features of aerosol size distributions inferred from spectral optical thicknesses measured at Tsukuba in the three winter seasons; the size distribution is one of important parameters determining the single scattering properties of aerosols. Then from the measurements, an optical model of the volcanic stratospheric aerosols originated from the eruption of E1 Chichon has been constructed, and possible effects of the El Chichon volcanic aerosols on 
the solar radiation have been evaluated for the ('82-'83) winter, and compared with available observations.

\section{Optical thickness of the atmosphere}

The optical thickness of the atmosphere can be determined from the Beer-BouguerLambert law, expressing attenuation of the direct solar beam in the atmosphere, in the from :

$$
F(\lambda)=F_{0}(\lambda) \exp (-\tau(\lambda) m),
$$

where $F(\lambda)$ is the monochromatic solar irradiance reaching an instrument detector at wavelength $\lambda ; F_{0}(\lambda)$ the irradiance incident on the top of the atmosphere; $m$ the optical air mass, a function of solar zenith angle $\theta_{0}$ $\left(m=\sec \theta_{0}\right.$, for $\left.\theta \lesssim 75^{\circ}\right)$. The total optical thickness, $\tau(\lambda)$, of a vertical air column at wavelength $\lambda$ is represented by the sum of three components: the Rayleigh scattering by air molecules $\tau_{R}(\lambda)$, absorption by atmospheric gases such as ozone, water vapor, and carbon dioxide $\tau_{g}(\lambda)$, and extinction (scattering + absorption) by aerosols, $\tau_{a}(\lambda)$. That is,

$$
\tau(\lambda)=\tau_{R}(\lambda)+\tau_{g}(\lambda)+\tau_{a}(\lambda) .
$$

The Rayleigh optical thickness $\tau_{R}(\lambda)$ can be evaluated from the Rayleigh scattering cross section and the molecular density of the atmosphere. Among many published values, we have adopted the value by Fröhlich and Shaw (1980) with Young's correction (1981) for the depolarization ratio (cf. Asano et al., 1983).

Fig. 1 displays an example of spectral dis-

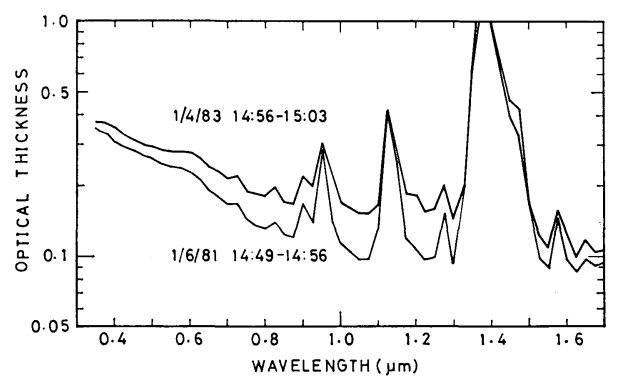

Fig. 1 Spectral distribution of the atmospheric optical thickness subtracted with the Rayleigh scattering component for measurements at $14: 49-14: 56$ on Jan. 6, 1981 and at $14: 56$ $15: 03$ on Jan. 4, 1983. tributions of the total optical thickness subtracted with the Rayleigh optical thickness, or $\tau(\lambda)-\tau_{R}(\lambda)$, for two cases. In the figure, the rather broad maxima around $\lambda=0.6 \mu \mathrm{m}$ are due to overlapping of the ozone Chappuis band absorption. The ozone absorption component was removed by using the total amount of ozone measured at the neighboring Aerological Observatory at Tateno $\left(36.1^{\circ} \mathrm{N}, 140.1^{\circ} \mathrm{E}\right)$. The absorption coefficients of ozone are taken from Inn and Tanaka (1953). In the near infrared region, we estimate the aerosol optical thickness from the total optical thickness in the window regions between absorption bands of water vapor. In this study we refer to the aerosol optical thickness $\tau_{a}(\lambda)$ as a measure of the atmospheric turbidity.

\section{Spectro-pyrheliometer}

The spectro-pyrheliometer used to measure the total optical thickness $\tau(\lambda)$ of the atmosphere is a double-monochromator composed of a diffraction grating and a quartz prism. It is installed on the equatorial mounting so that it can automatically track the sun with the aid of a sun-follower synchronized to the pyrheliometer. The measured wavelength range is between $0.35 \mu \mathrm{m}$ and $2.0 \mu \mathrm{m}$. The ultraviolet and visible radiation is detected by a photomultiplier, and the near infrared radiation by a $\mathrm{PbS}$ photo-cell. The characteristics and calibration techniques of the instrument have been explained in detail as a newly designed specro-pyrheliometer in Murai et al. (1977).

The spectro-pyrheliometer was calibrated by the common Langley plot method. The Langley method requires a constant optical thickness over a time period of observations. Since temporal and spatial fluctuations in various atmospheric parameters are to be expected, apparently correct but erroneous result can arise from a single application of the method (Shaw, 1983). At Tsukuba we have very few chances of stable clear days. The calibration constant at each wavelength was determined by averaging several calibrations made on comparatively stable, clear days throughout the seasons. The accuracy is rather low, and errors are estimated to be about $10 \%$ in the aerosol optical thickness for 


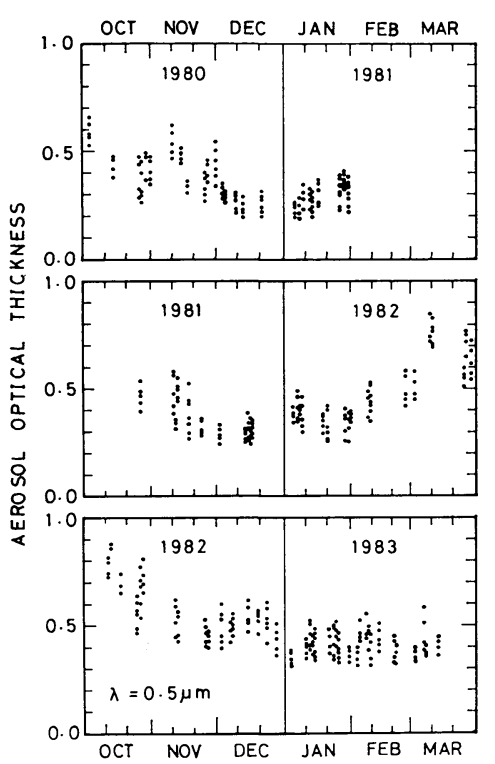

(a)

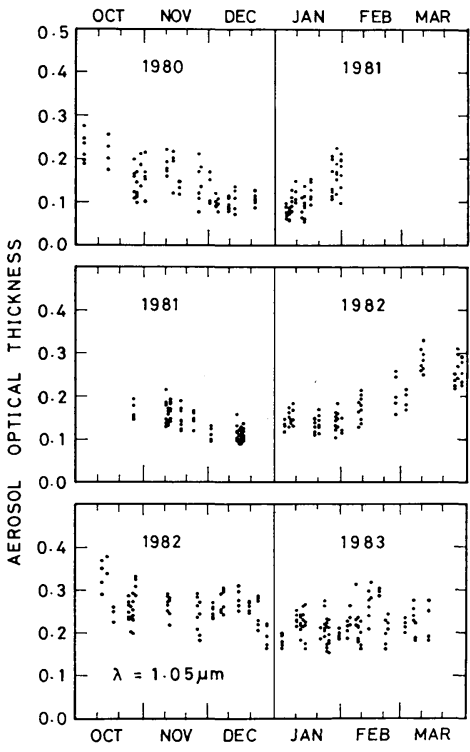

(b)

Fig. 2 Aerosol optical thickness versus observation date. (a) Wavelength $\lambda=9.5 \mu \mathrm{m}$, (b) Wavelength $\lambda=1.05 \mu \mathrm{m}$.

observations at $m \geq 2$. The accuracy may be lower for shorter wavelengths, because of larger deviations among the calibrations due to steeper slopes of the Langley plots (or larger optical thicknesses) for shorter wavelengths.

\section{Variation of the atmospheric turbidity}

Spectral measurements of the direct solar radiation were carried out at MRI on cloudless days in three winter seasons from late autumn in 1980 to early spring in 1983 . The daily observations were fixed neither in time nor in number; the latter varied from a few to several times a day. Figs. 2(a) and (b) show time variations of the aerosol optical thicknesses at wavelengths $\lambda=0.50 \mu \mathrm{m}$ and $1.05 \mu \mathrm{m}$ respectively for the three seasons. The abscissa indicates observation dates. The vertical scattering of data points represents temporal variations in an observation day; the variations may be mainly due to local, temporal fluctuations of tropospheric aerosols. From the figures we can see that we have few stable days suitable for the Langley calibration in a winter season at Tsububa. The ('80-'81) and ('81-'82) seasons exhibit a typical pattern of seasonal variation, but, for the ('82-'83) season, the annual minimum turbidity occurred near the end of January 1983. In addition, the optical thickness for the level of daily minima* increased from winter season to next winter season; especially the base level values of the optical thickness for the ('82-'83) season is much larger comared to the prior two seasons. The increase of the base level optical thickness can be seen more evidently in the near infrared region, as shown in Fig. 2(b) (See also Fig. 1).

The aerosol optical thickness $\tau_{a}(\lambda)$ obtained from spectral measurements of the direct solar radiation is due to total aerosols in the vertical air column, and it does not contain any information about height distribution of aerosols. In addition, aerosol optical properties and hence the turbidity are subject to weather influences, particularly, to relative humidity (e.g., Murai et al., 1973; Nilsson, 1979; Ta-

* In this paper the term "daily mirimum" simply implies the minimum value among several optical thicknesses measured over a limitted time period in a day, not the real minimum for the whole day. Hereafter, we shall call the level the base level. 


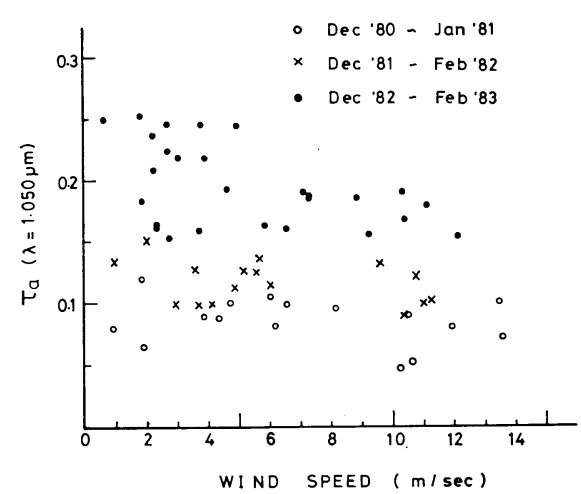

(a)

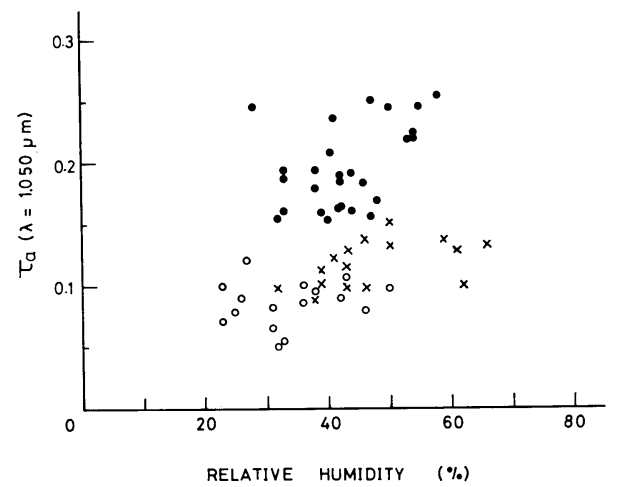

(b)

Fig. 3 (a) Correlation between the base level aerosol optical thickness at wavelength $i=$ $1.05 \mu \mathrm{m}$ and the wind speed measured simultaneously at height $213 \mathrm{~m}$ from the ground.

(b) Same as (a), except for correlation with the relative humidity.

kamura et al., 1984). So we can not simply attribute the dominant increase of the ('82-'83) season's base level to an enhancement of stratospheric aerosols. As an aid to seek a cause of the increase, we have investigated correlations between the aerosol optical thickness and the meteorological elements in the lower troposphere.' In Figs. 3(a) and (b), the base level values of the aerosol optical thickness at $\lambda=1.05 \mu \mathrm{m}$ are plotted, against wind speed and relative humidity respectively. The wind speed and the relative humidity were measured at the top (height $213 \mathrm{~m}$ ) of the MRI meteorological tower concurrent with the optical thickness measurement. The wind direction at that height was mostly westerly (NW-WSW) in the relevant seasons, except for several days on which the Kanto plain was under migratory anticyclone; winds on those days were generally calm or weak easterly and the turbidity tended to be relatively high. The pattern of variation in the ('82-'83) season, without extremely different weather situations, looks like similar to that in the previous seasons, but the mean value of $\tau_{a}(\lambda)$ at $\lambda=1.05 \mu \mathrm{m}$ for the ('82-'83) winter is larger by about 0.1 , suggesting that the difference may not be related to local variations in the troposphere. Further, Yamauchi and Shimura (1984) have reported the secular variations of the Feussner-Dubois turbidity factor (cf. Asano et al., 1983) at the fourteen observation stations of the Japan Meteorolog- ical Agency, and revealed that after the eruption of $\mathrm{El}$ Chichon the turbidity factor increased abnormally with the increase appearing earlier at southern stations. The large turbidity has brought a reduction of broadband direct solar radiation at noon time by 20\% averaged over Japan in December 1982. This reduction corresponds to an increase of the atmospheric optical thickness by nearly 0.1 averaged over the entire solar spectrum. In addition, from the observation by the MRI ruby lidar, Uchino et al. (1984) have reported the long term variation of stratospheric aerosol layers after the eruption of El Chichon, and estimated the stratospheric optical thickness at the lidar wevelength $(\lambda=0.6943 \mu \mathrm{m})$ of 0.164 for December 1982. From the above considerations, we can attribute, at least, a major part of the surprisingly large increase of the base level optical thickness in the ('82-'83) season to stratospheric aerosols originated from the eruption of $\mathrm{El}$ Chichon, not to measurement errors nor local and/or temporal tropospheric fluctuations. Hereafter, we shall call the ('80-'81) and ('81-'82) winter seasons the pre-El Chichon season, and the ('82-'83) winter season the post-El Chichon season.

\section{Characteristics of aerosol size distributions}

For the post-El Chichon season, not only the base level optical thickness is larger than that for the pre-El Chichon season, but also 
the wavelength dependence of $\tau_{a}(\lambda)$ is different as shown in Fig. 1. Assuming that aerosols are homogeneous, spherical particles, size distributions of total aerosols in the vertical air column can be estimated by means of the socalled inversion method from spectral optical thickness measurements (e.g., King et al. 1978; Yamamoto and Tanaka, 1969). The inversion method is discussed in detail in Appendix.

Fig. 4. shows aerosol size distributions for clear days at the base level for the pre- and post-El Chichon seasons, respectively. The size distribution is represented as the volume spectrum $d V c / d \ln r$ per air column, where $r$ and $V c$ are the radius and the cumulative volume of particles in the vertical air column, respectively. We have assigned different values of the complex refractive index $M$ of aerosols for the pre- and post-El Chichon seasons. However, a little difference in the refractive index does not change overall features of the inferred size distributions. The aerosol volume spectra for the pre-El Chichon season exhibit bimodal feature with enhancements at smaller and larger sizes. On the other hand, all the spectra for the post-El Chichon season are rather smooth with little

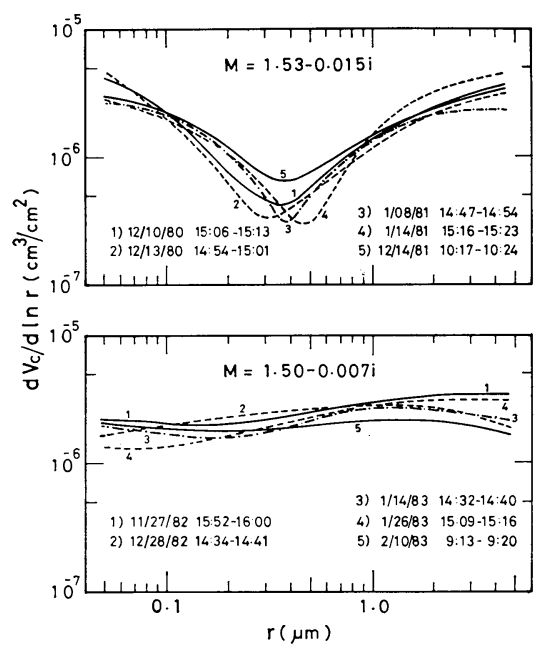

Fig. 4 Volume-size distribution of aerosols in the vertical air column. Top: Volume spectrum inferred from the spectral optical thicknesses $\tau_{a}(\lambda)$ measured on clear days in the pre-El Chichon season, assuming the complex refractive index of $M=1.53-0.015 i$. Bottom: Same as the top, except for the post-El Chichon season with $M=1.50-0.007 i$. variation with radius, showing a feature of power law size distribution. It is also noteworthy that the post-El Chichon spectra involve larger number of particles in the size range between $0.2 \mu \mathrm{m}$ and $1.0 \mu \mathrm{m}$.

\section{Model of the stratospheric aerosols due to the eruption of El Chichon}

On the assumption that the base level optical thickness, subtracted with the contamination by the eruption of El Chichon, for the ('82'83) winter season is the same as the base level optical thickness for the pre-El Chichon season, we estimate the increased optical thickness due to stratospheric aerosols originated from the eruption of $\mathrm{El}$ Chichon from our spectral measurements of the direct solar radiation.

Fig. 5 (a) shows monthly means of the base level optical thicknesses in December for the pre-El Chichon season and the post-El Chichon season, and their difference. The difference $\Delta \tau_{a}(\lambda)$ may be regarded as the stratospheric optical thickness associated with the El Chichon volcanic aerosols. The values of $\Delta \tau_{a}(\lambda)$ are fairly large in visible to near infrared region; the background optical thickness of the stratosphere is quite small, say, $\sim 0.005$ (Turco et al., 1982). In the figure stratospheric optical thicknesses estimated from solar extinction measurements by photometers are compared. The values by Michalsky et al. (1984) were estimated by the similar method to the present study from ground-based measurements. On the other hand, Dutton and DeLuisi (1983) estimated the stratosphric optical thickness from sunphotometer measurements made on board a NASA CV-990 aircraft during December 1982 .

According to the MRI lidar measurements (Uchino et al., 1984), remarkable changes of the stratospheric aerosol layer were noticed from December 1982 through January 1983. That is the lowering of the maximum backscattering height from $22.5 \mathrm{~km}$ to $18-19 \mathrm{~km}$ and the decrease of the integrated backscattering coefficients. A corresponding figure for January is shown in Fig. 5(b). The monthly mean base level optical thicknesses for the pre-El Chichon season are nearly same in December 


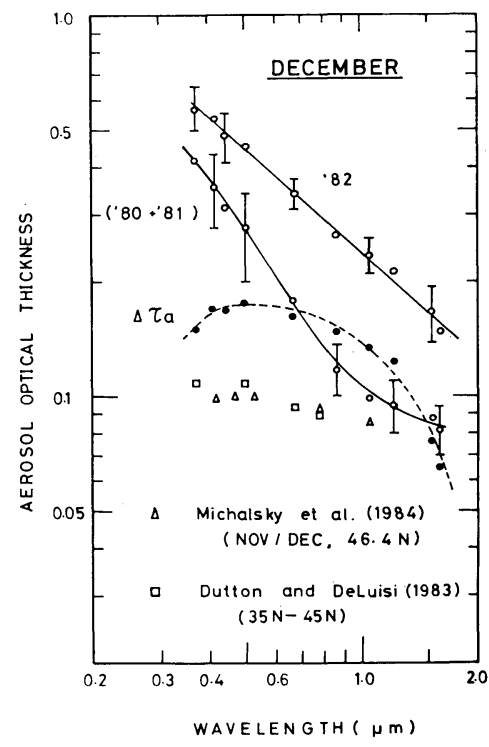

(a)

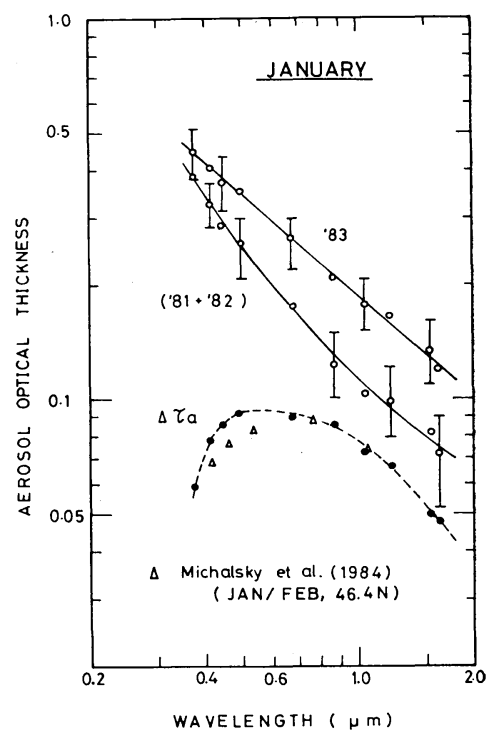

(b)

Fig. 5 Wavelength dependence of aerosol optical thickness. (a) December model. Monthly means and standard deviations of daily minimum optical thicknesses measured in December in the pre- and post-El Chichon seasons. $\Delta \tau_{a}$ are the difference of the means for the pre- and post-El Chichon seasons. (b) Same as (a), except for January model.

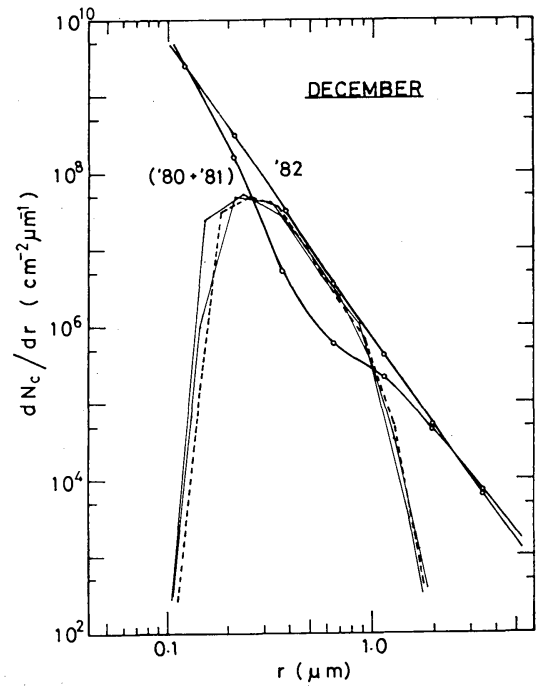

(a)



(b)

Fig. 6 Number-size distribution of aerosols in the vertical air column. (a) December model. The size distributions were inverted from the aerosol optical thicknesses at those wavelengths shown in Fig. 5 (a). Three different distributions retrieved from $\Delta \tau_{a}(\lambda)$ are due to different size limits employed in the inversion scheme. (b) January model. Size distributions inverted from the optical thicknesses in Fig. 5 (b). 
and in January, however, for the post-El Chichon season the optical thickness in the January model is much smaller than in the December model, resulting in a decrease of $\Delta \tau_{a}(\lambda)$ in the January model. This decrease well corresponds to the falling off of the integrated lidar backscattering coefficient.

Aerosol size distributions inverted from optical thicknesses, $\tau_{a}(\lambda)$ and $\Delta \tau_{a}(\lambda)$, in Figs. 5 (a) and (b) are drawn in Figs. 6(a) and (b), respectively, for the December and January models. The size distributions in cumulative aerosol number per air column show features, as previously mentioned, of bimodal distribution for the pre-El Chichon season and of power law distribution for the post-El Chichon season. For the latter the size distribution can be approximated by $d N c / d r \propto \gamma^{-3.8}$, where $N c$ is the aerosol number per unit area per unit radius interval in the vertical air column. On the other hand, size distribution inverted from $\Delta \tau_{a}(\lambda)$ in Figs. 5 (a) and (b) are relatively monodispersive, with a peak in number size distribution near $0.25 \mu \mathrm{m}$ and $0.35 \mu \mathrm{m}$, respectively, for the December and January models.

Our relatively monodispersive size distributions for stratospheric aerosols agree well with the size distribution obtained by Michalsky et al. (1984) for their JAN/FEB observations at $46.4^{\circ} \mathrm{N}$. On the other hand, size distributions of stratospheric aerosols were measured on board the NASA U-2 aircraft using particle size spectrometers by Knollenberg and Huffman (1983), and using palladium wire impactors by Oberbeck et al. (1983) over the North America continent. These in situ measurements have revealed that after September 1982 stratospheric aerosols were largely $\mathrm{H}_{2} \mathrm{SO}_{4}$ droplets with bimodal size distributions, whose mode radii in number-size distribution were about $0.2 \mu \mathrm{m}$ and $0.6 \mu \mathrm{m}$ in December through January; the larger modal size was larger for lower altitudes and increased with time. Our monodispersive size distributions resemble to a smoothed contour of their bimodal distributions without depression in intermediate sizes and with cut-off for smaller sizes; small particles of $r<0.1 \mu \mathrm{m}$ are optically less effective and hardly retrieved accurately by the inversion. The relatively monodispersive size dis- tributions may be a result of inversion with a rather low size resolution from $\Delta \tau_{a}(\lambda)$, which are considered as the stratospheric aerosol optical thickness integrated over height and time (a monthly average).

In summary, we specify stratospheric aerosols in the ('82-'83) winter originated from the eruption of $\mathrm{El}$ Chichon as $\mathrm{H}_{2} \mathrm{SO}_{4}$ droplets whose optical thickness and size distribution are shown respectively in Figs. 5 and 6. For the aerosol models, the integrated backscattering coefficients at the ruby lidar wanelength $\lambda=0.6943 \mu \mathrm{m}$ are $3.8 \times 10^{-3} \mathrm{SR}^{-1}$ and $2.2 \times 10^{-3}$ $\mathrm{SR}^{-1}$, respectively, for the December and January models. These values agree quite well with the MRI lidar observation by Uchino et al. (1984) of $3.3 \times 10^{-3} \mathrm{SR}^{-1}$ and $2.3 \times 10^{-3}$ $\mathrm{SR}^{-1}$, respectively. For the December model, our value is larger by about $15 \%$ than the lidar observation value. This and the comparison in Fig. 5 (a) suggest that $\Delta \tau_{a}(\lambda)$ in our December model seem to be a little overestimated; but we believe that the stratospheric optical thickness at that time over Tsukuba was not so small as the values estimated by Michalsky et al. (1984) and Dutton and Deluisi (1984) (See the next section).

\section{Effects of the stratospheric aerosols on the solar radiation budget}

Radiative transfer computations were carried out on a simple model atmosphere to study effects of the above specified stratospheric aerosols arisen from the eruption of El Chichon on the solar radiation budget. The model atmospere consists of two homogeneous layers, the stratosphere and the troposphere separated by the $150 \mathrm{mb}$ surface, and an underlying Lambertian surface with albedo $A s=0.15$. In addition to scattering and absorption by aerosols, radiative processes of the Rayleigh scattering by air molecules, as well as absorption by ozone and water vapor, respectively, in the stratospheric and tropospheric layers are treated. The absorption coefficients of water vapor are taken from Kerschgens et al. (1976) in the form of the exponential series expansion for the band transmission functions. The average amounts of ozone and water vapor for winter seasons 
at Tsukuba are assumed. The single scattering properties of aerosols were calculated from the Mie theory. Fig. 7 shows wavelength dependence of the single scattering albedo and the asymmetry factor for the tropospheric and stratospheric aerosols with the size distribution shown in Fig. 6(a) for the December model. Solar fluxes for the wavelength in-

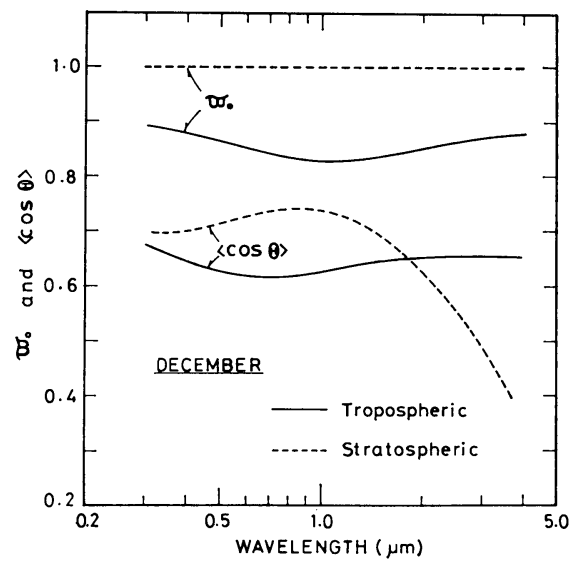

Fig. 7 Wavelength dependence of the single scattering albedo $\widetilde{\omega}_{0}$ and the asymmetry factor $\langle\cos \Theta\rangle$ for the tropospheric and stratospheric aerosols of which sice distributions are given by the solid line of (' $80+$ ' 81 ) and the broken line, respectively, in Fig. 6 (a) for the December model.

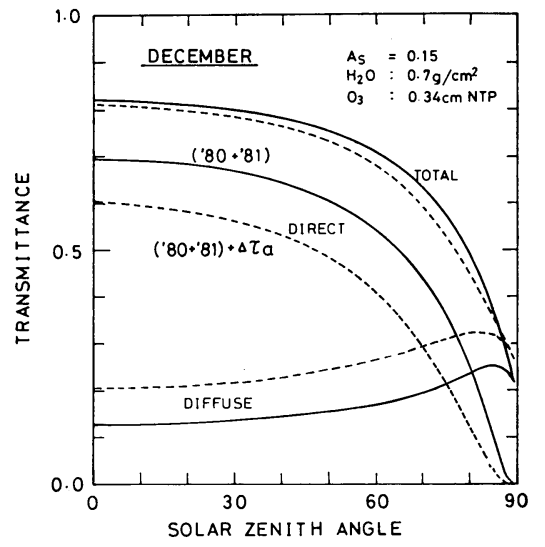

Fig. 8 Flux transmittance for the direct, diffuse and total (global) solar radiation, as a function of solar zenith angle, for the December model. Solid lines: Tropospheric aerosols of the pre-El Chichon monthly mean model without stratospheric aerosols. Dashed lines: Tropospheric aerosols plus stratospheric aerosols specified as the El Chichon induced aerosols. terval from 0.3 to $4.0 \mu \mathrm{m}$ were evaluated by dividing the interval into 24 subintervals with the doubling-adding method for multiple scattering computations (cf. Liou, 1982). The extraterrestrial solar spectral irradiance from the World Radiation Center has been utilized in this study (Iqbal, 1983; WMO, 1982).

Fig. 8 shows flux transmittance, as a function of the solar zenith angle $\theta_{0}$, for the direct, diffuse and total (global) solar radiation for the December model. The broken and solid lines indicate respectively the cases with and without the stratospheric aerosols specified in the preceding section. The addition of stratospheric aerosols brings a great decrease in the direct transmittance and a slight decrease in the total transmittance as a result of a compensating increase of the diffuse transmittance. However, the decrease of the global solar radiation is significantly large for the cases of rather large solar zenith angles as in winter at Tsukuba. At $\theta_{0}=60^{\circ}$ or $m=2$, for example, the addition of stratospheric aerosols decreases the directly transmitted flux by $91 \mathrm{~W} / \mathrm{m}^{2}$ and increases the diffusely transmitted flux by $68 \mathrm{~W} / \mathrm{m}^{2}$, resulting in a reduction of the total (global) flux by $23 \mathrm{~W} / \mathrm{m}^{2}$, for the mean extraterrestrial solar flux of $1430 \mathrm{~W} / \mathrm{m}^{2}$ in December. These values. well correspond to the solar radiation budget observed at the Tateno Aerological Observatory; from Table 2 in Obata (1984), comparison of monthly mean values at apparent noon on clear days for December in 1982 with those in 1980 and 1981 shows that the direct solar flux was smaller by $86 \mathrm{~W} / \mathrm{m}^{2} \quad(20 \%$ decrease), and the diffuse flux was larger by $63 \mathrm{~W} / \mathrm{m}^{2}$ (71\% increase), while the global solar flux was smaller by $14 \mathrm{~W} / \mathrm{m}^{2}$ ( $3 \%$ decrease). Again our December model slightly overestimates the effects of stratospheric aerosols due to the eruption of El Chichon.

For the January model, effects of the stratospheric aerosols on the solar radiation at the ground are much smaller but still appreciable. For example, again at $\theta_{0}=60^{\circ}(m=2)$, addition of the January model stratospheric aerosols reduces the direct transmittance by $0.078(15 \%)$, and increases the diffuse transmittance by 0.058 $(32 \%)$, thus results in a decrease of 0.020 . 
$(2.8 \%)$ in the total transmittance. At the top of the atmosphere, on the other hand, the addition of stratospheric aerosols increases the spherical (global) albedo for cloudless earthatmosphere system by $0.026(14 \%)$ and 0.016 $(8 \%)$, respectively, for the December and January models with $A s=0.15$.

\section{Concluding remarks}

On the ground-based, spectral attenuation observations of the direct solar radiation at Tsukuba, the aerosol optical thickness has been obtained for the three winter seasons from October 1980 to March 1983. The aerosol optical thickness in the ('82-'83) winter season was surprisingly large by about 0.1 on the wavelength average as compared with that for the previous two seasons. This increase of aerosol optical thickness can be attributed to the enhancement of stratospheric aerosols arisen from the eruption of El Chichon.

Size distributions of aerosols in the vertical air column were inverted from aerosol optical thicknesses at selected wavelenths. The aerosol size distributions for clear days are characterized as bimodal distribution for the pre-El Chichon season and as power law distribution for the post-El Chichon season. On the other hand, the size distribution for the stratospheric aerosols due to the eruption of El Chichon are relatively monodispersive.

On the assumption that stratospheric aerosols in the ('82-'83) winter over Tsukuba were mostly $\mathrm{H}_{2} \mathrm{SO}_{4}$ droplets with the above inferred optical thickness and size distribution, possible effects of the stratospheric aerosols due to the eruption of El Chichon on the clear days' solar radiation budget in that season were estimated and compared with observations at the Tateno Aerological Observatory. The model stratospheric aerosols can reduce the global solar radiation on the ground by as much as $3-4 \%$, and enhance the spherical albedo by about $10 \%$ on cloudless days.

Although the predicted and observed effects of the volcanic stratospheric aerosols are in fairly good agreement in the above comparison in Fig. 8, the computed directly transmitted fluxes both for the cases with and without the stratospheric aerosols are smaller than the observed values at the Tateno Aerological Observatory for December in 1982 and (1980+ 1981) respectively, while the computed diffuse fluxes are larger than the corresponding observations. This suggests that our measurements might systematically overestimate the aerosol optical thickness by about $10 \%$ on the wavelength average both for the pre- and post-El Chichon seasons. Another cause of the disagreement in the directly transmitted fluxes may be partly due to different apertures between our spectro-pyrheliometer and the broadband pyrheliometer used at the Tateno Aerological Observatory; the broadband pyrheliometer has a much wider aperture of $8^{\circ}$. instead of $2^{\circ} \times 4^{\circ}$ (rectangle) of ours. Thus the broadband pyrheliometer could be more subject to errors arising from scattered circumsolar radiation. On the other hand, the diffusely transmitted fluxes are very sensitive not only to the aerosol optical thickness and size distribution but also to the complex refractive index of aerosols. The preassigned value of $M=1.53-0.015 i$ for tropospheric aerosols might be a little smaller, especially for the imaginary part, than some 'actual' value expected for aerosols in dry winter seasons (Takamura et al., 1984). A larger imaginary part of the refractive index can yield a smaller single scattering albedo and result in a smaller diffuse transmittance. However these uncertainties in the aerosol optical thickness measurement and in the aerosol model do not alter the above stated general results obtained in this study.

Evaluation of climatic effects of volcanic stratospheric aerosols should be based on realistic models of volcanic aerosols, since different microphysical and optical properties are to be expected for each volcanic activity, location, season, time after eruption, and so on. Accurate spectral measurements of the optical thickness both for stratospheric and tropospheric aerosols are efficient means of and highly desirable in constructing reasonable optical models of aerosols.

\section{Acknowledgements}

The authors wish to thank Dr. T. Takamura of the National Defence Academy for 
useful comments and a critical reading of the manuscript. Thanks are also to Mr. T. Yasuda, Planning Division of JMA, for his kind advice in writing the manuscript in English.

\section{Appendix}

In order to invert aerosol size distribution per air column from spectral optical ticknesses, we have employed the scheme proposed by King et al. (1978) with a slight modification. The complex refractive index was a priori set to be $M=1.53-0.015 i$ for tropospheric aerosols and $M=1.45-0.0 i$ for stratospheric aerosols, for all wavelengths. For aerosols in the air column in the ('82-'83) season, the value $M=$ $1.50-0.007 i$ was assumed as a weighted mean of the above two values. The sensitivity of the inverted size distribution to the refractive index has been investigated by Yamamoto and Tanaka (1969) and King et al. (1978). They showed that the inverted size distributions maintain their shape for slight changes of the refractive index. With input of $\tau_{a}(\lambda)$ at ten wavelengths between $0.37 \mu \mathrm{m}$ and $1.625 \mu \mathrm{m}$, aerosol number densities at ten sizes between the size limits $0.04 \mu \mathrm{m} \leq r \leq 8 \mu \mathrm{m}$ were inverted; meaningful retrieved size distribution may be restricted within $0.1 \mu \mathrm{m} \leqslant r \leqslant 3 \mu \mathrm{m}$ for the present scheme.

The wavelength range of input data $\tau_{a}(\lambda)$ can affect the inversion of size distribution.

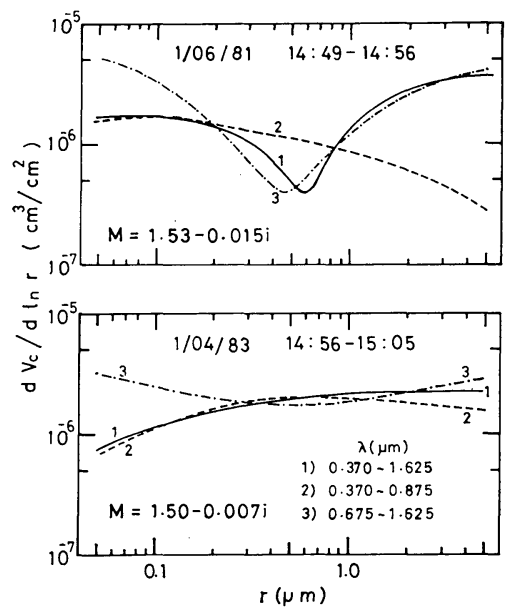

Fig. A Effects of wevelength ranges of input data $\tau_{a}(\lambda)$ of aerosol optical thicknesses on the inversion of size distribution for the cases shown in Fig. 1.
Fig. A displays an example of the effect of different wavelength ranges on inversion of the volume spectrum for the two cases shown in Fig. 1. For power law type size distribution such as the case of $1 / 04 / 83$, input data $\tau_{a}(\lambda)$ in the visible region are enough to estimate entire size spectrum. However, for bimodal type size distribution such as the case of $1 / 06 / 81$, the larger mode can not be retrieved from $\tau_{a}(\lambda)$ only in the visible region. Thus, spectral optical thickness measurements by sunphotometers with a silicon photo-diode detector are not enough to estimate bimodal type size distributions. Nakajima et al. (1983) have obtained bimodal size distributions by inverting combined data of aerosol optical thicknesses measured by a sunphotometer and phase functions inferred from aureole measurements.

\section{References}

Asano, S., K. Murai and T. Yamauchi, 1983: An improvement of the computation method of the atmospheric turbidity factors. J. Meteor. Research, 35, 135-144 (in Japanese with English abstract).

Baker, C.B., W.R. Kuhn and E. Ryznar, 1984 : Effects of the El Chichon volcanic cloud on direct and diffuse solar irradiances. J. Climate and Appl. Meteor., 23, 449-452.

Dutton, E. and J. DeLuisi, 1983: Spectral extinction of direct solar radiation by the El Chichon cloud during December 1982. Geophy. Res. Letters, 10, 1013-1016.

Fröhlich, C. and G.E. Shaw, 1980: New determination of Rayleigh scattering in the terrestrial atmosphere. Appl. Optics, 19, 1773-1775.

Hu, H., 1984 : Measurements with a spectral pyranometer at Tucson after the eruption of El Chichon volcano. J. Atmos. Sci., 41, 1662-1666.

Inn, E.C.Y. and Y. Tanaka, 1953: Absorption coefficients of ozone in the ultraviolet and visible regions. J. Opt. Soc. Am., 43, 870-873.

Iqbal, M., 1983: "An Introduction to Solar Radiation", Academic Press (New York), p. 44-50.

Kerschgens, M., E. Raschke and U. Reuter, 1976 : The absorption of solar radiation in model atmospheres. Beitr. Phys. Atmos., 49, 81-97.

King, M. D., B. M. Byrne, B. M. Herman and J. A. Reagan, 1978: Aerosol size distributions obtained by inversion of spectral optical depth measurements. J. Atmos. Sci., 35, 2153-2167.

Knollenberg, R. G. and D. Huffman, 1983: Measurements of the aerosol size distribution in the El Chichon cloud. Geophy. Res. Letters, 10, 10251028. 
Liou, K. N., 1980: "An Introduction to Atmospheric Radiation", Academic Press (New York), p. 216220.

Michalsky, J. J., B. M. Herman and N. R. Larson, 1984: Mid-latitude stratospheric aerosol layer enhancement by El Chichon: The first year. Geophys. Res. Letters, 11, 76-79.

Murai, K., M. Kobayashi and R. Goto, 1973: Scattering functions of the atmospheric aerosols measured by the polar nephelometer. Papers Meteor. Geophys., 24, 233-248.

- - - Ground-based spectral measurements of solar radiation (I) Extinction and size distribution of aerosol particles in the atmosphere. Papers Meteor. Geophys., 28, 169-184.

Nakajima, T., M. Tanaka and T. Yamauchi, 1983 : Retrieval of the optical properties of aerosols from aureole and extinction data. Appl. Optics, 22, 2951-2959.

Nilsson, B., 1979: Meteorological influence on aerosol extinction in the $0.2-40 \mu \mathrm{m}$ wavelength range. Appl. Optics, 18, 3457-3473.

Obata, M., 1984: On the result of solar radiation observation at Tateno Aerological Observatory: With relation to the 1982-eruption of El Chichon volcano. J. Aerological Obs. Tateno, 44, 37-43 (in Japanese with English abstract).

Oberbeck, V.R., E. F. Danielsen, K. G. Snetsinger, G. V. Ferry, W. Fong and D. M. Hayes, 1983 : Effect of the eruption of El Chichon on stratospheric aerosol size and composition. Geophys.
Res. Letters, 10, 1021-1024.

Shaw, G.E., 1983: Sun photometry. Bull. Amer. Meteor. Soc., 64, 4-10.

Takamura, T., M. Tanaka and T. Nakajima, 1984 : Effects of atmospheric humidity on the refractive index and size distribution of aerosols as estimated from light scattering measurements. J. Meteor. Soc. Jpn, 62, 573-582.

Uchino, O., K. Takahashi, I. Tabata, I. Akita, Y. Okada and K. Naito, 1984: Ruby lidar observations of the El Chichon dust clouds at Tsukuba $\left(36.1^{\circ} \mathrm{N}\right)$ and comparisons with UV lidar measurements at Fukuoka $\left(33.6^{\circ} \mathrm{N}\right)$. J. Meteor. Soc. Jpn, 62, 679-687.

Wendler, G., 1984: Effects of the El Chichon volcanic cloud on solar radiation received at Fairbanks, Alaska. Bull. Amer. Meteor. Soc., 65, 216-218.

WMO, 1982 : Commission for Instruments and Method of Observation, Abridged Final Report of the Eighth Session (Mexico City, 19-30 October 1981). WMO-NO. 590, p. 71-75.

Yamamoto, G. and M. Tanaka, 1969: Determination of aerosol size distribution from spectral attenuation measurements. Appl. Optics, 8, 447453.

Yamauchi, T. and H. Shimura, 1984: The effect of El Chichon eruption in 1982 on the atmospheric turbidity. Tenki, 31, 533-544 (in Japanese).

Young, A.T., 1981: On the Rayleigh scattering optical depth of the atmosphere. J. Appl. Meteor., 20, 328-330.

\title{
筑波における冬季の大気混濁度とエーロゾルの粒径分布： エル・チチョン火山噴火の影響
}

\author{
浅野正二・関根 正幸 ${ }^{1)}$ 小 小林 正治 ${ }^{2}$ ・村井潔 三 ${ }^{3)}$ \\ 気象研究所
}

筑波の気象研究所において，1980年10月から1983年 3 月の間の 3 回の冬季シーズンに，直達日射の分光測定 を行い，エーロゾル大気の光学的厚さの変動を観測した。('82-'83) 冬季の光学的厚さは，それ以前 2 シーズ ンに比べて異常な程大きく, エル・チチョン火山噴火にともなら成層圈エーロゾルの増加によりもたらされた と考觉られる。

測定された光学的厚さの波長分布から, エーロゾルの粒径分布が推算された。エル・チチョン噴火以前のシ 一ズンの粒径分布は, bimodal 分布の特徵を示し, エル・チチョン噴火後のそれは, 指数則分布の特徵を呈し ている。また，エル・チチョン噴火に起因する（'82-'83）冬季の成層圈エーロゾルの光学的性質が推定され た。この時期の成層圏の太陽放射に対する平均の光学的厚さは, 約 0.1 であり, 成層圏エーロゾルの粒径分布 は, ほぼ monodispersive であった。

この成層圏エーロゾルの太陽放射収支に対する効果を評価するため，簡単なモデル大気における太陽放射伝 達の計算を行い, 観測值と比較した。その結果, この時期のエル・チチョン噴火に起因する成層圈エーロゾル は, 晴天日の地上到達全天日射量を 3 4\% 減じ, 地表一大気系のグローバルアルベードを約 $10 \%$ 高める効 果を持つことが判った。

現所属 1. 気象庁産業気象課 2. 日野市旭ケ丘 5-2-13 3. 気象大学校 